\title{
THE STORY OF A RE-OPERATING WINDMILL
}

\author{
Enikő BITAY, ${ }^{1}$ László MÁRTON, ${ }^{2}$ János TALPAS ${ }^{3}$ \\ ${ }^{1}$ Sapientia Hungarian University of Transylvania, Târgu-Mureș, Romania, ebitay@ms.sapientia.ro \\ ${ }^{2}$ Transylvanian Museum Societe, Gheorgheni, Romania, martonlb@yahoo.com \\ ${ }^{3}$ Babeş-Bolyai University, Cluj-Napoca, Romania, talpasjanos@gmail.com
}

\begin{abstract}
Research on the history of the development of grain milling structures is a priority topic of the Department of Technical Sciences of the Transylvanian Museum Association. Quite a few publications and study volumes contain the results of the research. The present dissertation presents another grinding structure, the windmill, its reconstruction, creating a connection between the theoretical foundations and the practical implementation. Although it was built as a museum and tourist object, it is also a significant work from the point of view of technical history.

The Felsőszentiván windmill is powered by a 14-meter-diameter windmill. The mill has a two-stage accelerator gear that increases the low, non-grinding speed of the wind turbine for the rotation typical of grindstone mills.

The upper stones of a pair of grindstones rest on a vertical axis, and by raising this the gap between the stones can be adjusted. This determines the particle size of the grind. The windmill consists of three functional parts: a windmill, an accelerator gear and a grain mill made up of a pair of grindstones.
\end{abstract}

Keywords: windmill, gear transmission, grinding, grindstone pair

\section{Introduction}

The wind wheel is a typical source of energy for windmills, which converts the kinetic energy of the wind into rotational motion. The first windmills, built in the 7th century in Iran and Afghanistan, had a vertical axis. Participants in the Third Crusade (1189-1192) carried to the Middle East the product of Western Europe, the horizontal axis windmill. Windmills have been known in the Carpathian Basin since the 12th century and were built where, in the absence of fast-flowing streams, watermills could not conquer space [1]. ]. The location of the windmills had to take into account the annual average wind speed, which had to be between 2 and $5 \mathrm{~m} / \mathrm{s}$. The change in wind speed as a function of topography and height above ground level is shown in Figure 1.

Over the centuries, windmills became more and more complex and perfected, and by the 19th century, the version we see today was in use. Thus, the windmill became an important and inexpen- sive source of mechanical energy. The victory of the steam engine and its competition with the windmill are also connected to the 19th century.

\section{Purpose and area of application of the windmill}

The windmill is mainly used for the production of cereal and corn grist. The grind is whole meal groats, a typical product of screenless and millstone mills. The product is intended for animal feed and cornmeal can be used as human food after manual sieving.

Grinding capacity classifies it into the category of small mills.

By using it, we obtain high-quality animal feed in an energy-saving way. The windmill is also suitable for the production of whole wheat or rye flour, after sieving the primary flour through a sieve of suitable density.

In terms of mode of operation, both continuous and batch technology can be implemented with 


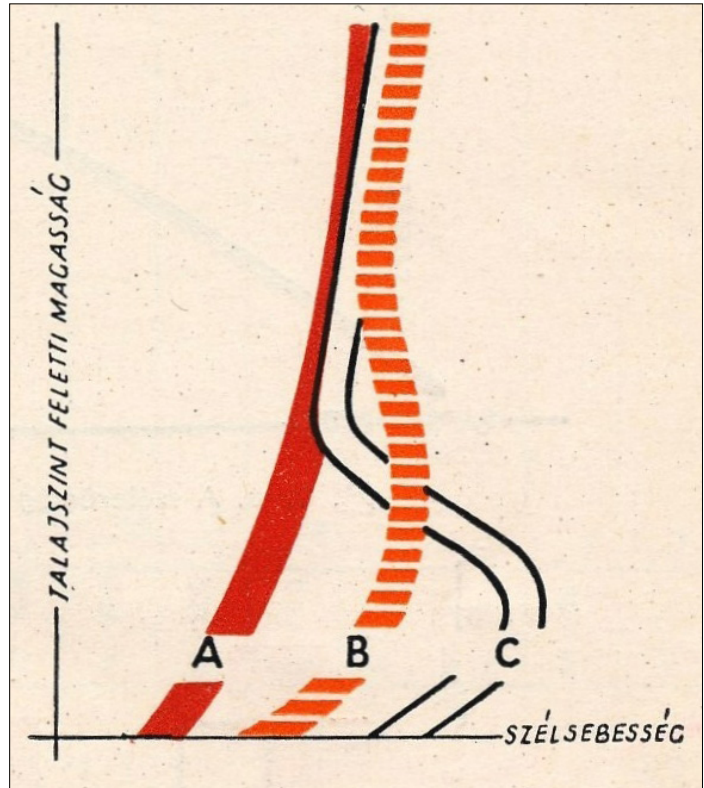

Figure 1. Variation of wind speed as a function of topography and height above ground level. [2]. A-in the flat countryside, B-in slightly hilly countryside, $\mathrm{C}-$ in the mountains.

the mill. It can be used to produce continuous grinding or to meet the specific needs of the population.

\section{Operation of the windmill}

The operation of a windmill is determined by three machine devices:

- grain cleaning unit;

- grinding unit;

- unit for energy transfer.

\subsection{The grain cleaning unit}

On the first level (ground floor) begins the technological process, the second phase is that of grain cleaning, abrasion. The first stage of cleaning is carried out by a sieve and a selector (tri) in the grain warehouse, before the grain is transported to the mill. In this cleaning phase, all foreign matter is removed from the grain. Only the cleaned grain will be ground. As mentioned, the second phase of cleaning is abrasion. The abrasive or peeler on the ground floor cleans the grains as they rotate and collide with a screen-like surface made of a steel wire of square cross-section forming the inner cylindrical shell of the abrasive. As a result of the collision, the edges of the square wire remove the surface layer of the grain, which contains undesirable contaminants. The detached shell layer is removed by the exhaust fan attached to the abrasive and transferred to a replication cyclone and dust filter bag. Grain cleaned of contaminants is forced to move axially by the rotating balls of the screw-mounted abrasive. In the abrasive, the helical movement directs the processed grains through the outlet. The outlet is in direct contact with the rubber band elevator, which lifts the clean grain to the first floor (second level) where the stone bench is located. As long as the abrasive is in operation, the squeegee lift will also operate.

\subsection{The grinding unit}

The grinding process takes place on the first floor level. After abrasion, the grain enters the receiving hopper of the milling unit. At this point, the upper, rotating stone of the grinding stone pair is already in rotation due to the rotation of the fork shaft.

The grain arriving into the large hopper will flow into the small hopper. By adjusting the angle of inclination of the hopper, the miller can change whether the grain flows between the stone pair faster or slower. The hopper is constantly shaking so the grain does not get stuck in it. The vibration is created by a rod in contact with the rotating stone. $[3,4]$. The section of the grinding device is shown in Figure 2. with the help of which its operation can also be studied.

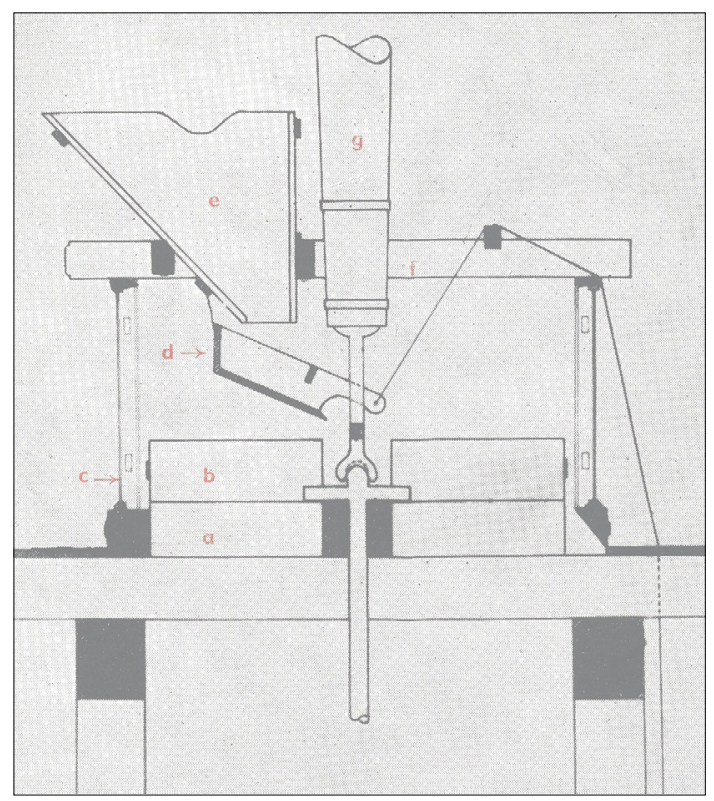

Figure 2. Section of the grinding unit. [2] 


\subsection{The unit for the energy transfer}

It is known that the force of the wind increases in proportion to the square of its velocity. The force of the wind is determined by its speed or its pressure per $\mathrm{m}^{2}$. Wind power on land varies according to the period of the day. During a day in the morning there is intensifying wind that will be strongest at noon, after that is it weakens until the night. The force of the wind also changes seasonally. A volume of air $(v \cdot F)$ can pass through the surface of a sail of size $(F)$ every second. The force $(P)$ applied to the cross section of the surface $F$ is proportional to the cubic speed:

$$
P=F \cdot v^{3} / 16 \text {. }
$$

Wind energy cannot be fully utilized because the wind continues to move between the sails, not stopping completely. Only a part of its energy can therefore be used. [2]

The efficiency applied to the wind wheel is 0.4 . Thus the value of the force $P$ will be as follows:

$$
P=0,4 \cdot F \cdot v^{3} / 16[\mathrm{kgF}] \text {. }
$$

The striking surface of a sail is $7 \times 1,2=8,4 \mathrm{~m}^{2}$, so in a wind of $4.0 \mathrm{~m} / \mathrm{s}$ the torque is:

$$
M=P \times L[\mathrm{kgF} \cdot \mathrm{m}] \text {, }
$$

whose power corresponds to M/75 [LE].

The grinding performance of a windmill depends on the wind speed.

During grinding, the stones wear out, and at intervals their grinding surface must be re-cut (sharpened). The operation requires expertise.

\section{The windmill of Felsőszentiván}

The windmill of Felsőszentiván was probably built in the middle of the $19^{\text {th }}$ century, and nearly a hundred years later, in 1920, it became the property of Vince Nagy Torma. The conical wall of the mill house was built of two layers. The inner half was adobe, the outer half was brick-walled. Nagy Torma Vince owned it until 1950, but had no financial means to renovate the slowly but surely deteriorating mill [5]. Because of this, in 2005, a piece several meters in diameter fell out of the windmill masonry (Figure 3). The remaining wreckage became unusable, moreover, dangerous. The machinery of the deteriorating mill is illustrated in Figure 4.

The owner, Vince Nagy Torma died in 1983. The shaping of the further fate of the mill was taken over by the municipality, which purchased the ruined mill and the land around it. The windmill was rebuilt from European Union tender funding. The construction works were carried out

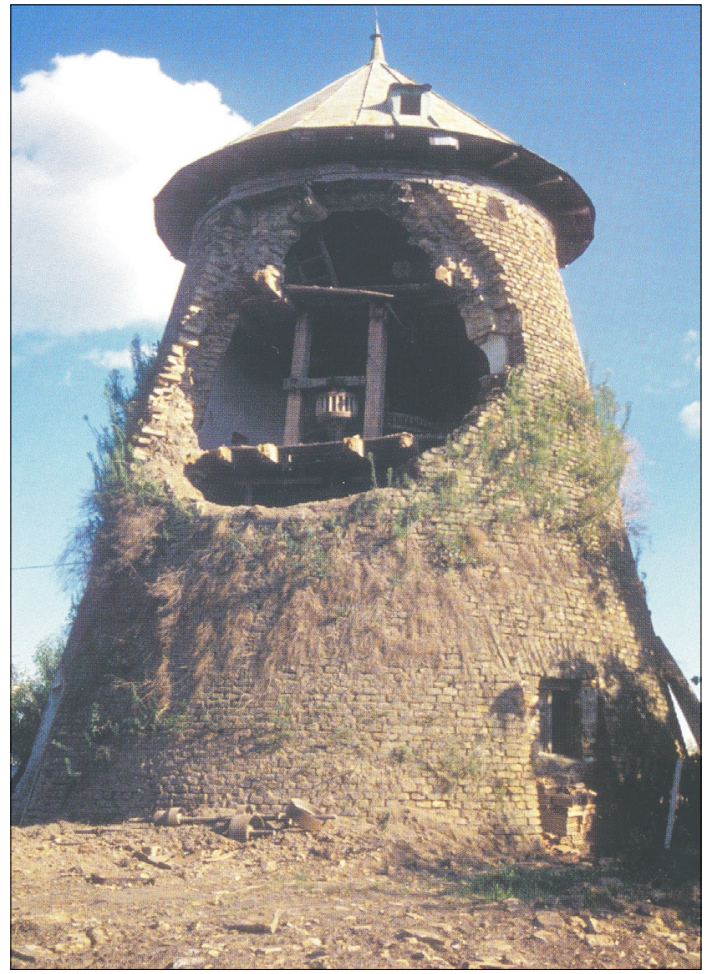

Figure 3. View of the Felsöszentiván windmill before reconstruction.

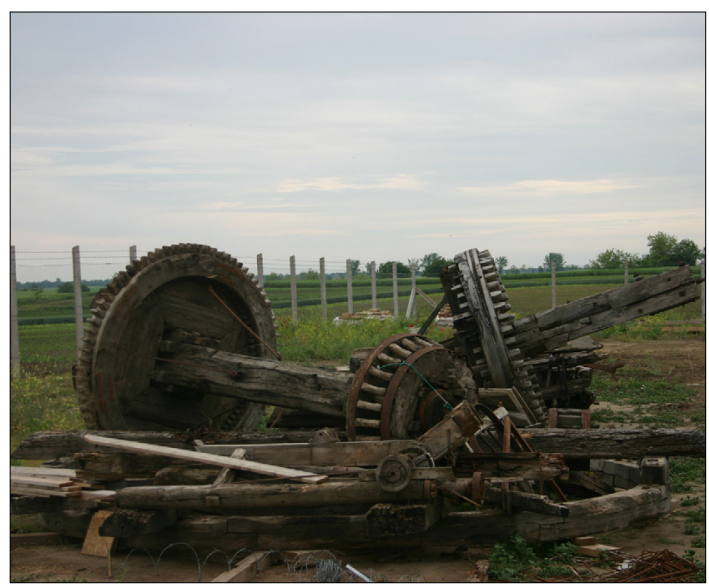

Figure 4. The old, deteriorating mill machines.

by Bajai Beton KFT, the milling machine and the wind wheel were undertaken by Mecatex KFT in Gyergyószentmiklós, which has extensive experience in the construction of traditional grinding structures. In order to gain this experience, the technical history camps organized annually by the Transylvanian Museum Society also provided an opportunity for documentation. All this hap- 
pened in 2019-2020. Both contractors completed their work on schedule, creating the only working windmill in Hungary (Figure 5).

Specifications:

- grinding capacity: $200-250 \mathrm{~kg} / \mathrm{h}$, depending on wind speed;

- product quality: wholemeal groats;

- percentage of grinding: $100 \%$, after sieving $70-80 \%$ depending on the quality of the grain;

-installed capacity: total power of the two stonepair grinding units, bucket elevator, abrasive and vacuum cleaner: $9 \mathrm{~kW}$;

-requires two people to operate.

Both the old and the new windmill contain two stone-pair grinding units, which can be operated simultaneously or separately. The installation of the windmill machinery and of the new windmill, the moments of its preparation are illustrated in Figures 6-11.

\section{Description and structure of the windmill}

According to the literature, the truncated coneshaped mill building is divided into four levels [6]. The ground floor part (I) is the flour level, the first floor part (II) is the stone level, the second floor part (III) is the gear wheel level, the third floor (IV) is the big wheel level (Figure 12). On the upper edge of the brick wall of the mill there is a roller track connected to a reinforced concrete wreath, which allows the roof structure of the mill to be rotated, together with the windy shaft and the side gear wind wheel.

Attached to the side-toothed wind wheel is the large drum wheel, the first accelerator, which transmits the rotational motion of the wind wheel to the idol axis in the vertical plane. Attached to the idol shaft is the speed wheel of the third level. The rotational motion of the gear wheel is taken over by the two small drum wheels which are fixed to the fork shafts. At this gear, a second accelerator stage is created for the mill, which rotates the top, rotating stone of the grindstone pair at $110-130 \mathrm{rpm}$. As this turns, the grain is shredded and ground. The floor-by-floor elements of the mill are shown in Figures 13-15.

The grinding units are located on the second level (first floor). With the right wind speed, both grinding units can operate. If the wind speed is less than $2.0 \mathrm{~m} / \mathrm{s}$, only this one grinding unit can be operated.

On the first level (ground floor) there is a Eureka lined abrasive for cleaning the grain, with a dust

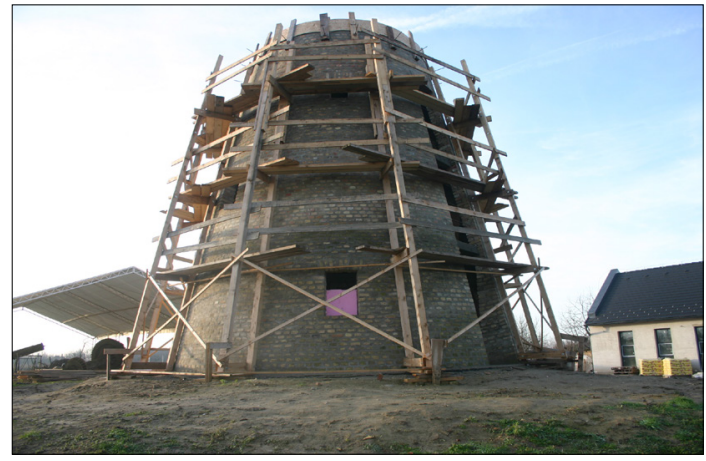

Figure 5. View of the Felsöszentiván windmill under reconstruction.

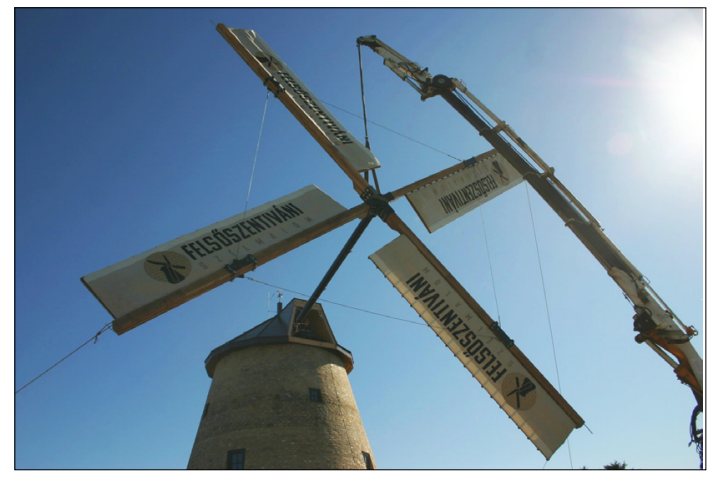

Figure 6. Lifting and repairing the wind wheel.

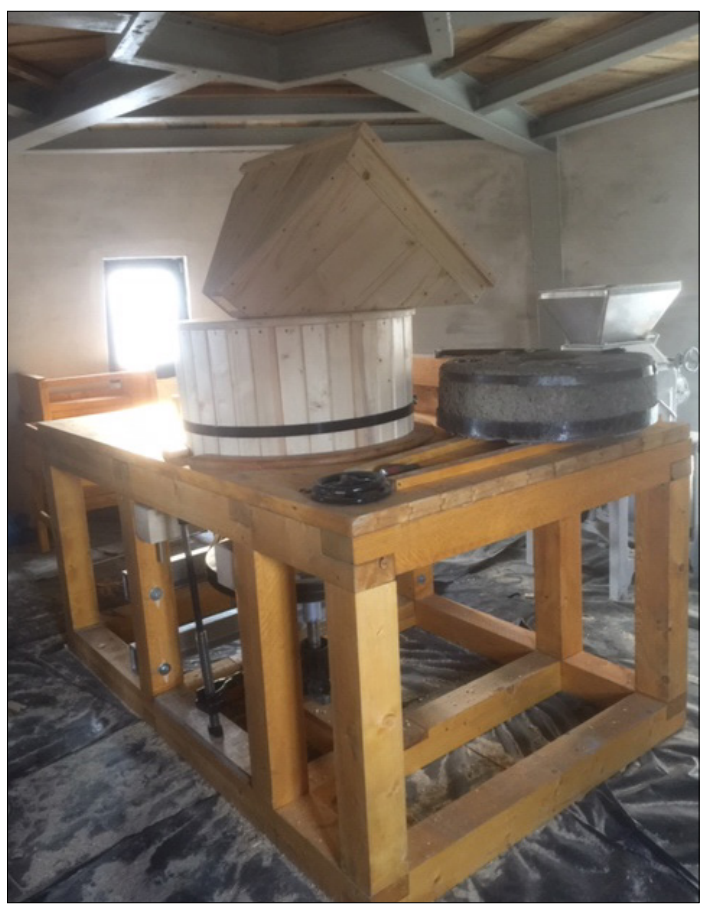

Figure 7. The windmill during installation. 


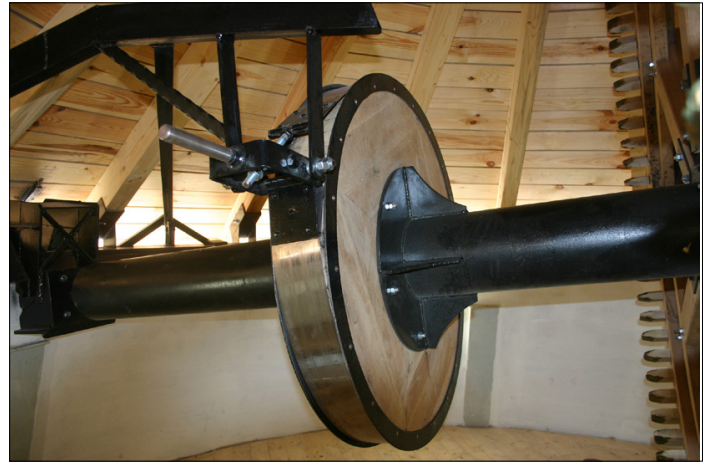

Figure 8. Brake structure of the windmill.

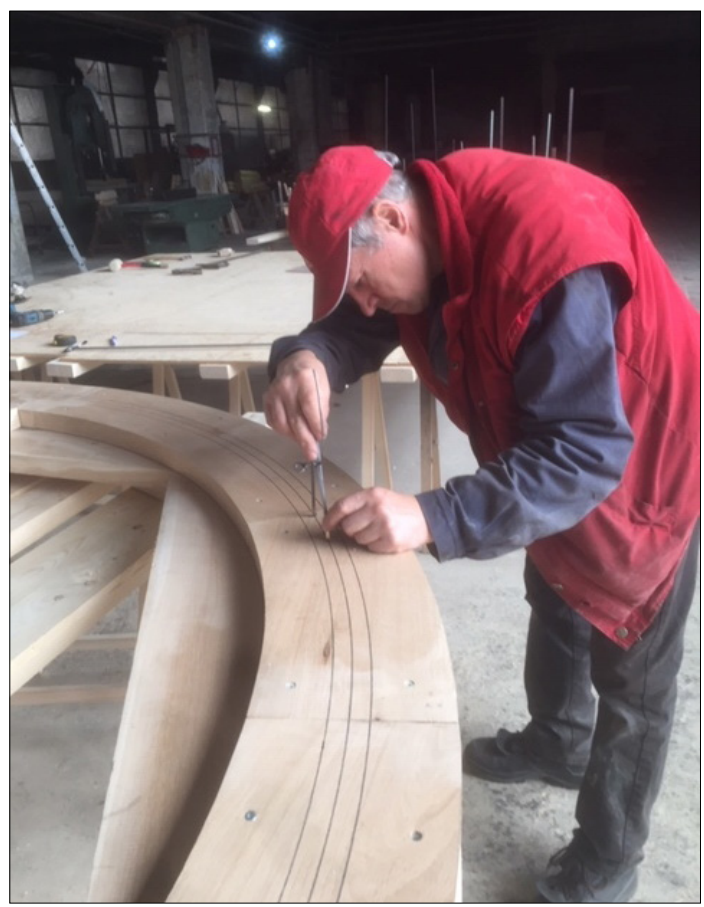

Figure 9. Gear tooth divisions.

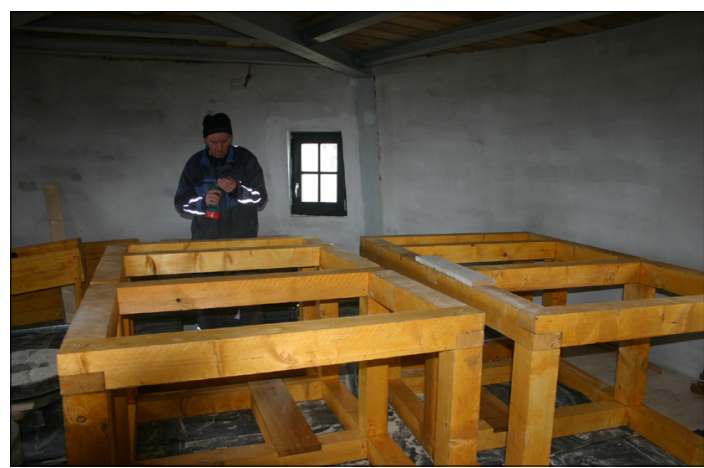

Figure 10. Assembly of the support structure of the mill machine.

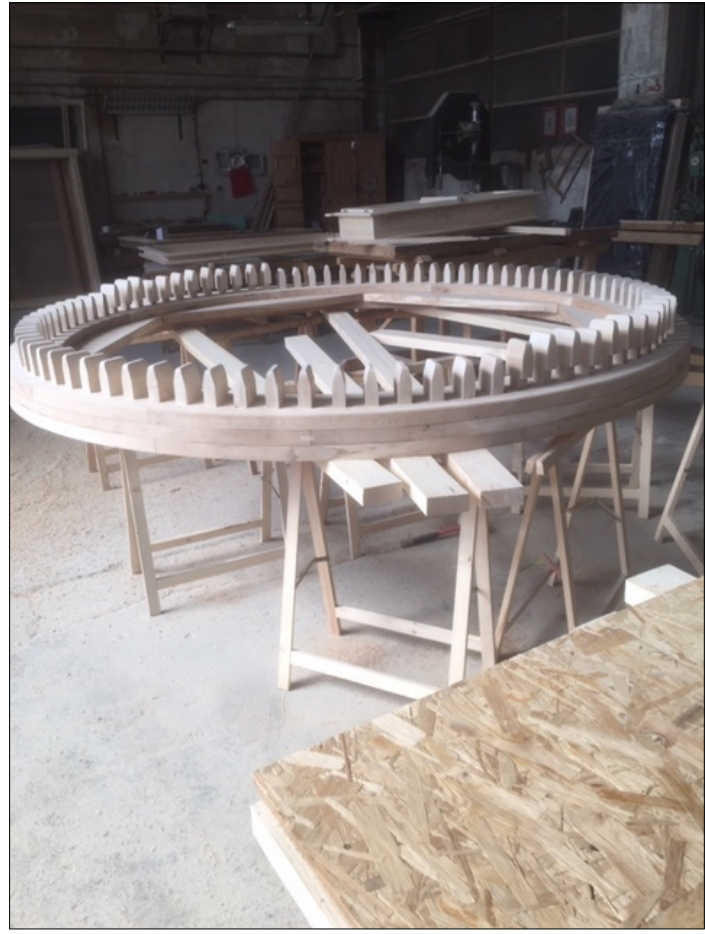

Figure 11. The semi-finished gear.

extractor and a dust filter unit. Inedible contaminants are removed from the surface of the grains by the abrasive. The worn grain is transferred to the hopper of the grinding units by a rubber-padded elevator.

The energy source of the mill is natural wind. The kinetic energy of the wind is converted into rotational motion by the sails of a wind wheel on an axis called the big idol [7]. Sails should always be set against the wind. This operation must be carried out with a winch designed for this purpose. The winch is located on the fourth level under the roof. The wind wheel is shown in Figure 16.

The grinding units of the windmill can also be operated separately.

In this case, the unused grinding unit must be switched off, which consists of lifting the fork shaft out of the disc iron and securing it in its raised position by means of a pin inserted in a hole provided for this purpose. This does not stop the rotation of the fork shaft, but does not transmit movement to the grindstone. 


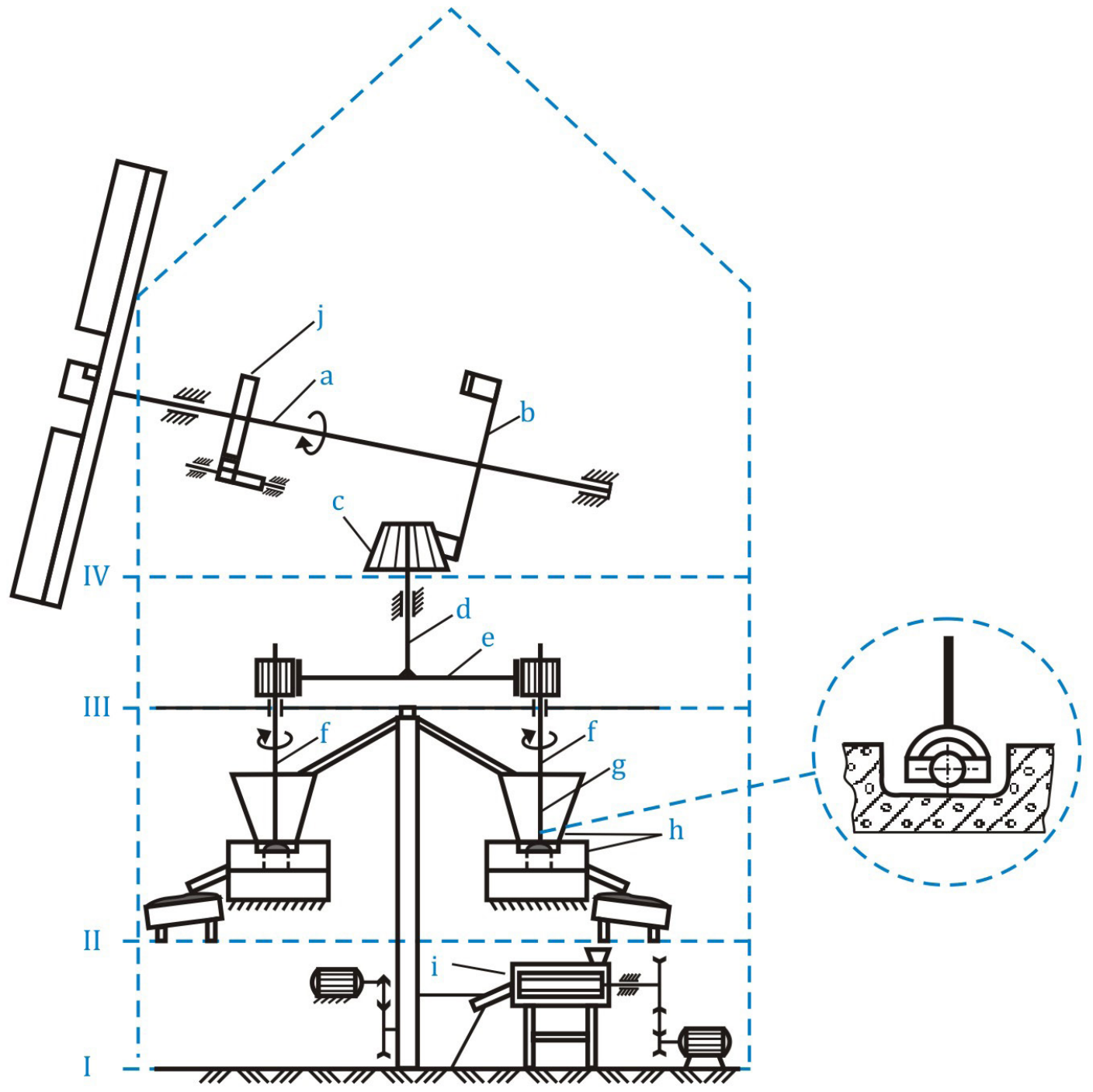

Figure 12. Structure of the windmill

I. flour level, II. Stone level, III gear wheel level, IV. Large wheel level

a. big idol, b. big wheel, c. large spool, d. small idol, e. gear wheel,

$f$. small spool, g. horn, $h$. stone with the hopper, i. abrasive, j. braking system. 


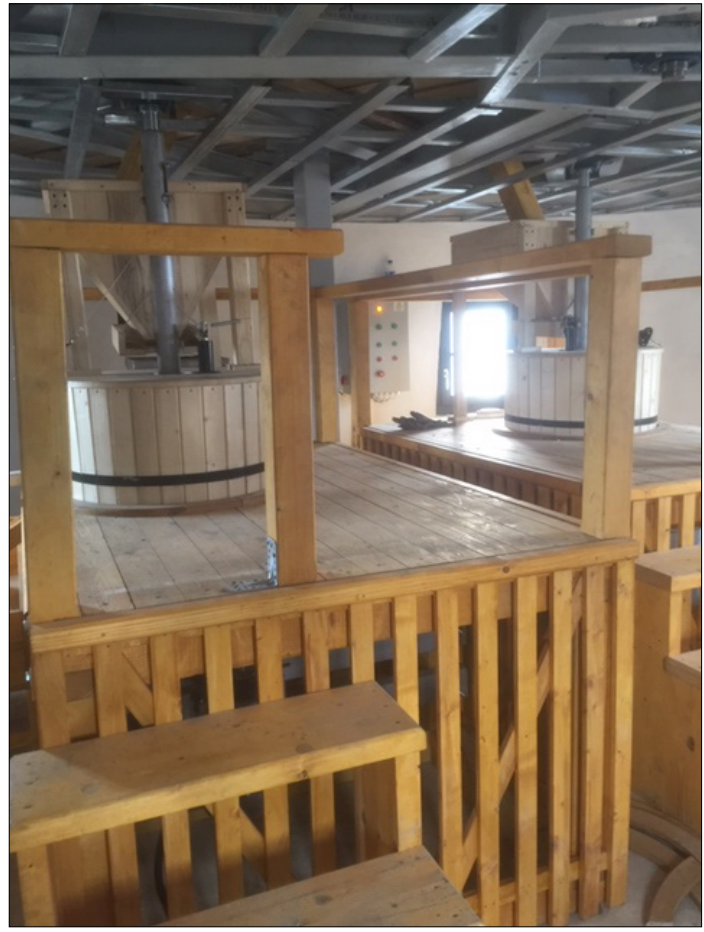

Figure 13. The machinery on the first floor.

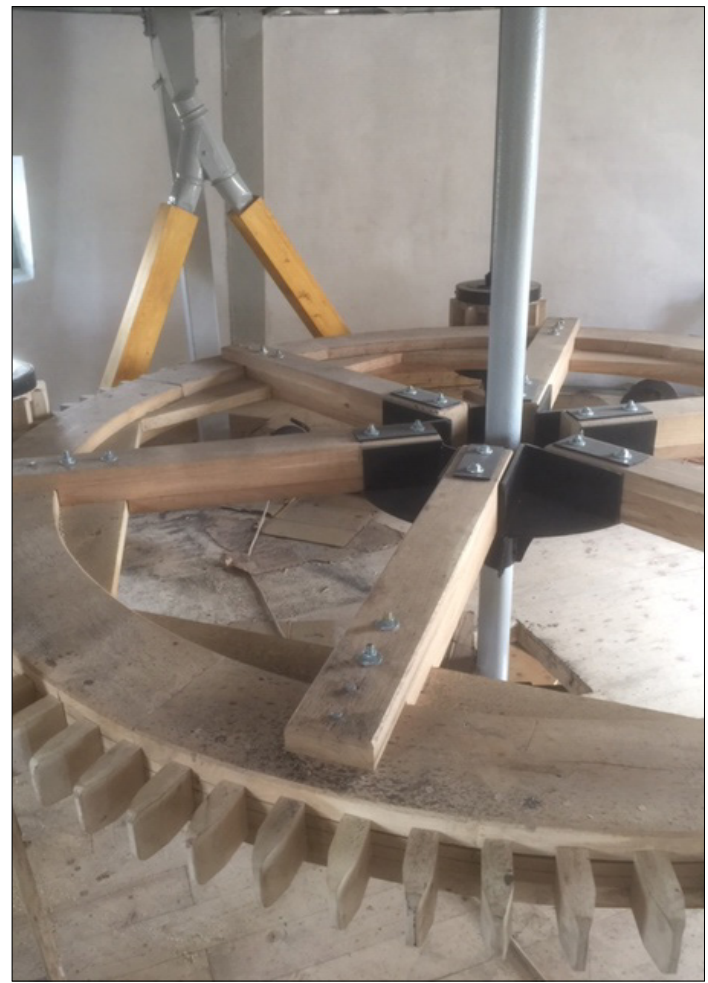

Figure 14. The machinery of the third floor.

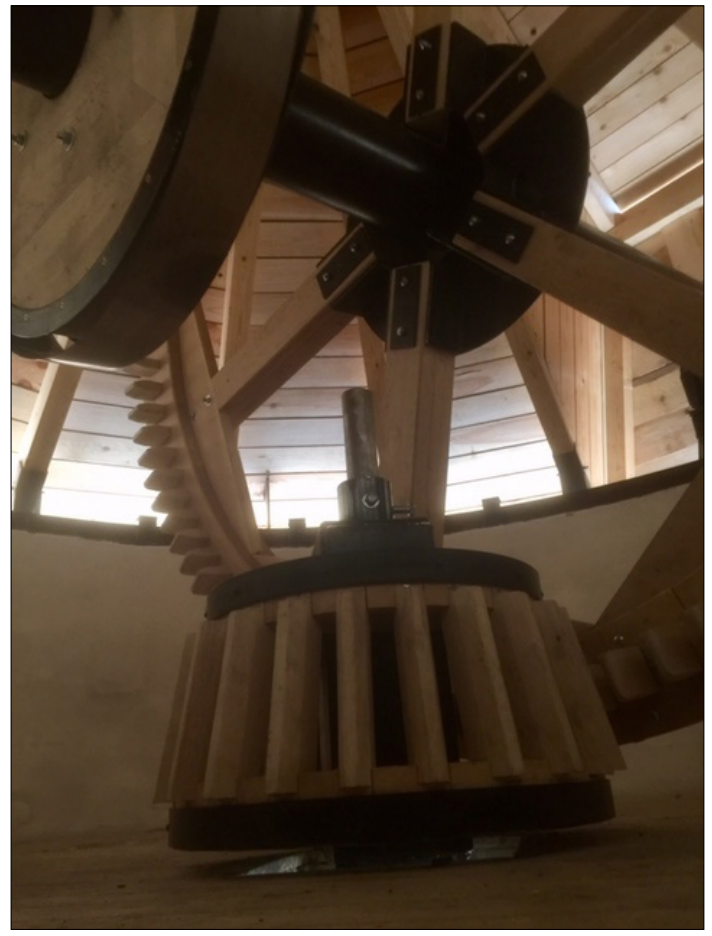

Figure 15. The machinery of the fourth floor.

\section{Conclusions}

With the reconstruction of Felsőszentiván windmill, the Department of Technical Sciences of the Transylvanian Museum Society (EME) set an example to follow again, proving that the theoretical knowledge of the multi-year research work of the members of the department can be put into practice with good results. The results of the mentioned technical history research work organized by EME can also be found in the design of the mill machine. The renovated or rebuilt mills of Szentendre, Mohács [8], Baja, and Felsőszentivan are on one hand significant tourist destinations, works of technical history and on the other hand testimonies to the use of renewable energy sources, especially in our century, when one of the pitfalls of sustainable development is energy. All this can be an example to follow in the future..

\section{References}

[1]Jean Gimpel: Revoluția industrială în Evul Mediu. Editura Meridiane, București, 1983. 29-32.

[2] Pongrácz Pál: A mezőgazdasági jellegü ipari építészet müemlékei. Építőipari és közlekedési Müszaki Egyetem Tudományos Közleményei, III/3. (1957). 


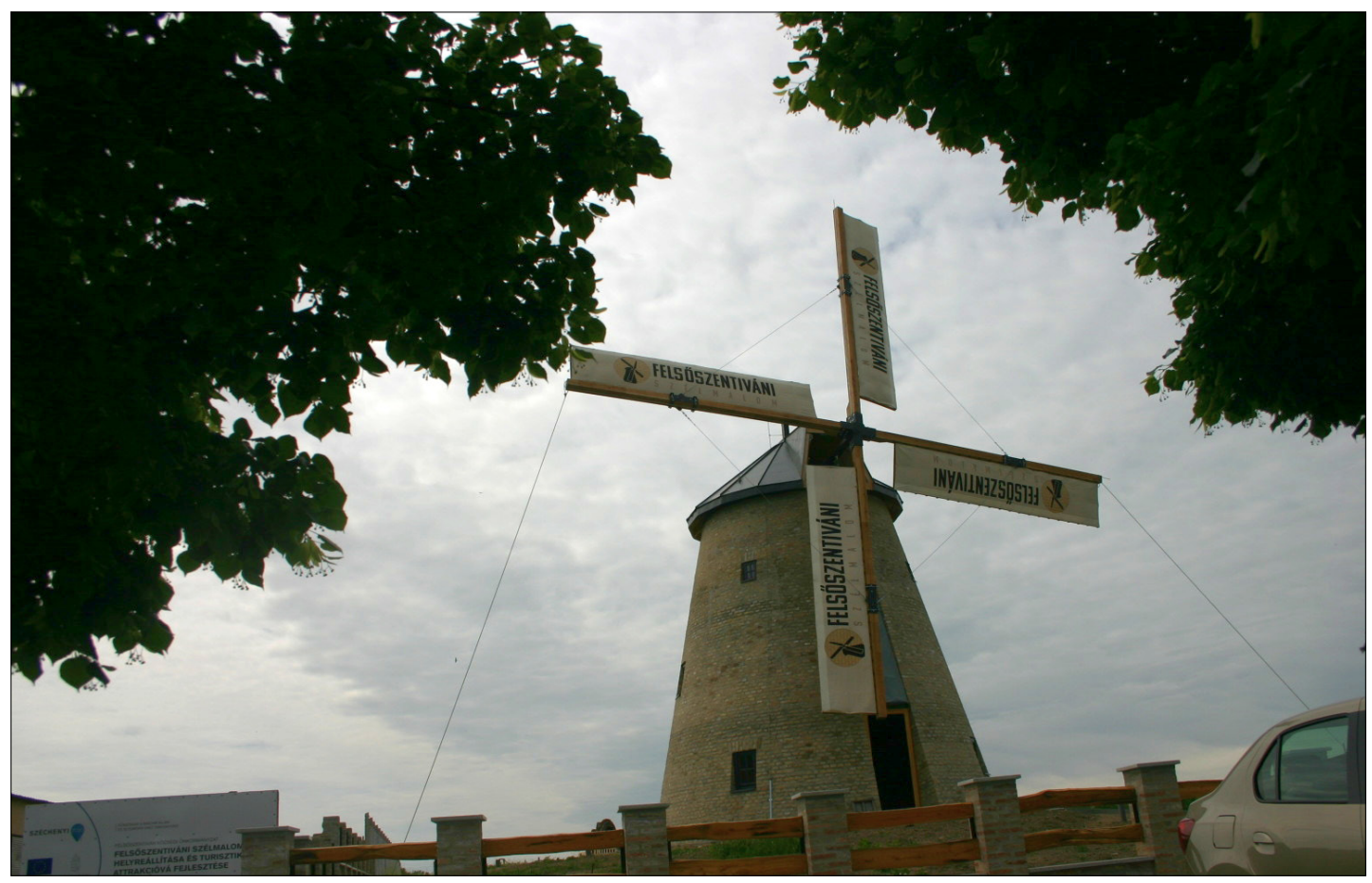

Figure 16. View of the ready for use windmill.

[3] Márton László: Vízimalmok Erdélyben. PallasAkadémia Könyvkiadó, Csíkszereda, 2003. 33-34.

[4] Bitay Enikő, Márton László: Székelyföldi vízimalmok térben és időben. In: Márton László (szerk.): Fejezetek Székelyföld technikatörténetéből. Erdélyi Múzeum-Egyesület, 2019. https://doi.org/10.36337/2019-01-08.

[5] Kovács József: Szélmalmaink. Romanika Kiadó, Budapest, 2005. 47, 50.
[6] Lambrecht Kálmán: A magyar szélmalom. Budapest, 1911. 19.

[7]Johannes Mager: Mülenflügel und Wasserrad. VEB Fachbuchverlag, Leipzig, 1987. 14-15.

[8] Bitay Enikő, Márton László, Mohácsi Bugárszki Norbert, Angi Norbert: Egy ókori gabonaőrlő szerkezet - a taposómalom újjászületése. In: Műszaki Tudományos Közlemények, 2. (2015) 55-60. https://doi.org/10.33895/mtk-2015.02.04. 